\title{
Seasonal variations in physico-chemical characteristics of Tuticorin coastal waters, southeast coast of India
}

\author{
S. Balakrishnan ${ }^{1} \cdot$ G. Chelladurai $^{2} \cdot$ J. $_{\text {Mohanraj }}{ }^{2} \cdot$ J. Poongodi $^{3}$
}

Received: 15 May 2015/ Accepted: 4 November 2015/Published online: 28 November 2015

(C) The Author(s) 2015. This article is published with open access at Springerlink.com

\begin{abstract}
Physico-chemical parameters were determined along the Vellapatti, Tharuvaikulam and Threspuram coastal waters, southeast coast of India. All the physicochemical parameters such as sea surface temperature, salinity, $\mathrm{pH}$, total alkalinity, total suspended solids, dissolved oxygen and nutrients like nitrate, nitrite, inorganic phosphate and reactive silicate were studied for a period of 12 months (June 2014-May 2015). Sea surface temperature varied from 26.4 to $29.7{ }^{\circ} \mathrm{C}$. Salinity varied from 26.1 and $36.2 \%$, hydrogen ion concentration ranged between 8.0 and 8.5. Variation in dissolved oxygen content was from 4.125 to $4.963 \mathrm{mg} \mathrm{l}^{-1}$. Total alkalinity ranged from 64 to $99 \mathrm{mg} / \mathrm{l}$. Total suspended solids ranged from 24 to $97 \mathrm{mg} / \mathrm{l}$. Concentrations of nutrients, viz. nitrates (2.047-4.007 $\mu \mathrm{M} / \mathrm{l})$, nitrites $(0.215-0.840 \mu \mathrm{M} / \mathrm{l})$, phosphates $\quad(0.167-0.904 \mu \mathrm{M} / \mathrm{l}), \quad$ total phosphorus (1.039-3.479 $\mu \mathrm{M} / \mathrm{l})$, reactive silicates $(3.737-8.876 \mu \mathrm{M} / \mathrm{l})$ ammonia $(0.078-0.526 \mu \mathrm{M} / \mathrm{l})$ and also varied independently.
\end{abstract}

Keywords Physico-chemical parameters · Nutrients · Southeast coast - Bay of Bengal

G. Chelladurai

chellam.zoo@gmail.com

1 Department of Marine Science, School of Marine Sciences, Bharathidasan University, Tiruchirappalli 620 024,

Tamil Nadu, India

2 Department of Zoology, Kamaraj College, Manonmaniam Sundaranar University, Tuticorin 03, Tamil Nadu, India

3 Department of Physics, Kamaraj College, Manonmaniam Sundaranar University, Tuticorin 03, Tamil Nadu, India

\section{Introduction}

Studies of pollution in natural ecosystem have many aspects, physical, chemical and biological. The physical aspects include the distribution of potential contaminants within the ecosystem. The chemical aspects include the level and chemical form of contaminants found within both the biotic and the abiotic components of ecosystem. But, it is recognition of the biological effects of contamination that defines the true significance of the physical and chemical contamination. Chemical analyses of water provide a good indication of the chemical quality of the aquatic systems, but do not integrate ecological factors such as altered riparian vegetation or altered flow regime, and therefore, do not necessarily reflect the ecological state of the system (Karr et al. 2000). The aquatic ecosystems are affected by some health stressors that extensively deplete biodiversity, the loss of biodiversity and its effects are predicted to be greater for aquatic ecosystems than for terrestrial ecosystems (Sala et al. 2000). To review the potentialities of any aquatic system, hydrobiological studies are very essential. Physico-chemical parameters are responsible for the spatio-temporal variations of all aquatic organisms. The investigations on meteorological and hydrographical features are necessary for assessing the fertility and productivity of any ecosystem (Rajasegar 2003). A number of researchers have studied the physical and chemical characteristics of some Indian estuaries (Anilkumar and Dineshkumar 2002; Thillai Rajasekar et al. 2005; Perumal et al. 1999). Though, considerable attention has been paid in the recent years to study the physico-chemical parameters of the coastal waters around India in order to ascertain the water quality and productivity, very little information is available on these aspects of the Palk Bay. The present study was made to obtain the present status of hydrographical parameters Vellapatti, Tharuvaikulam 
and Threspuram coastal waters, southeast of India. This information would be helpful in the ecological monitoring of this ecosystem.

\section{Materials and methods}

\section{Description of study area}

Tuticorin coast is located in the southeast coast of Bay of Bengal, Tamil Nadu. Three sampling stations were fixed, viz. Vellapatti (Lat. $08^{\circ} 11^{\prime} \mathrm{N}$; Long. $78^{\circ} 41^{\prime} \mathrm{E}$ ), Tharuvaikulam (Lat. $08^{\circ} 89^{\prime} \mathrm{N}$; Long. $78^{\circ} 16^{\prime} \mathrm{E}$ ) and Threspuram (Lat. $08^{\circ} 48^{\prime} \mathrm{N}$; Long. $78^{\circ} 94^{\prime} \mathrm{E}$ ) coastal region is having harbour with lot of fishing activities and a number of industries are situated along the coast discharging many effluents (Fig. 1). Further it is an important tourism centre with related activities. These stations were selected as they represent the north and central part of the southwest Bay of Bengal leaving the southern part intentionally as it is covered under the Gulf of Mannar National Park area with coral distribution where the environmental variables behave differently.

Several environmental variables were monitored and water samples were examined from over a period of 12 months during June 2014-May 2015. Sea surface temperature (SST) was measured using a digital multi-stem thermometer of $0.1{ }^{\circ} \mathrm{C}$ accuracy. Salinity was estimated using a hand-held refractometer (Atagohand refractometer,
Japan) and the $\mathrm{pH}$ (hydrogen ion concentration) was measured using a $\mathrm{pH}$ pen ( $\mathrm{pH}$ tester, Malaysia) with the accuracy of \pm 0.1 . Dissolved oxygen (DO) was estimated by the modified Winkler's Method (Strickland and Parsons 1972). Nutrients such as the nitrite $\left(\mathrm{NO}_{2}\right)$ was measured by a colorimetric method using sulfanilamide, nitrate $\left(\mathrm{NO}_{3}\right)$ by the cadmium reduction method, inorganic phosphorus (IP) and total phosphorus (TP) by the ascorbic acid method and reactive silicate by the molybdate method using a PCbased double-beam spectrophotometer (Systronics-2202).

\section{Results}

Physico-chemical parameters are considered as one of the most important features that are capable of influencing the marine environment and have showed wide temporal and spatial differences. All the physico-chemical parameters showed clear seasonal patterns, which are very typical to the tropical marine environment. Sea surface temperature recorded at three different stations ranged from 26.4 to $29.7{ }^{\circ} \mathrm{C}$. The minimum SST was observed during October 2014 and the maximum was registered during May 2015 at station-III (Fig 2a). The observed salinity values ranged between 26.1 and $36.2 \%$. The minimum salinity was observed during November 2014 at station II and the maximum was registered during May 2015 at station III (Fig. 2b). Hydrogen ion concentration ranged from 8.0

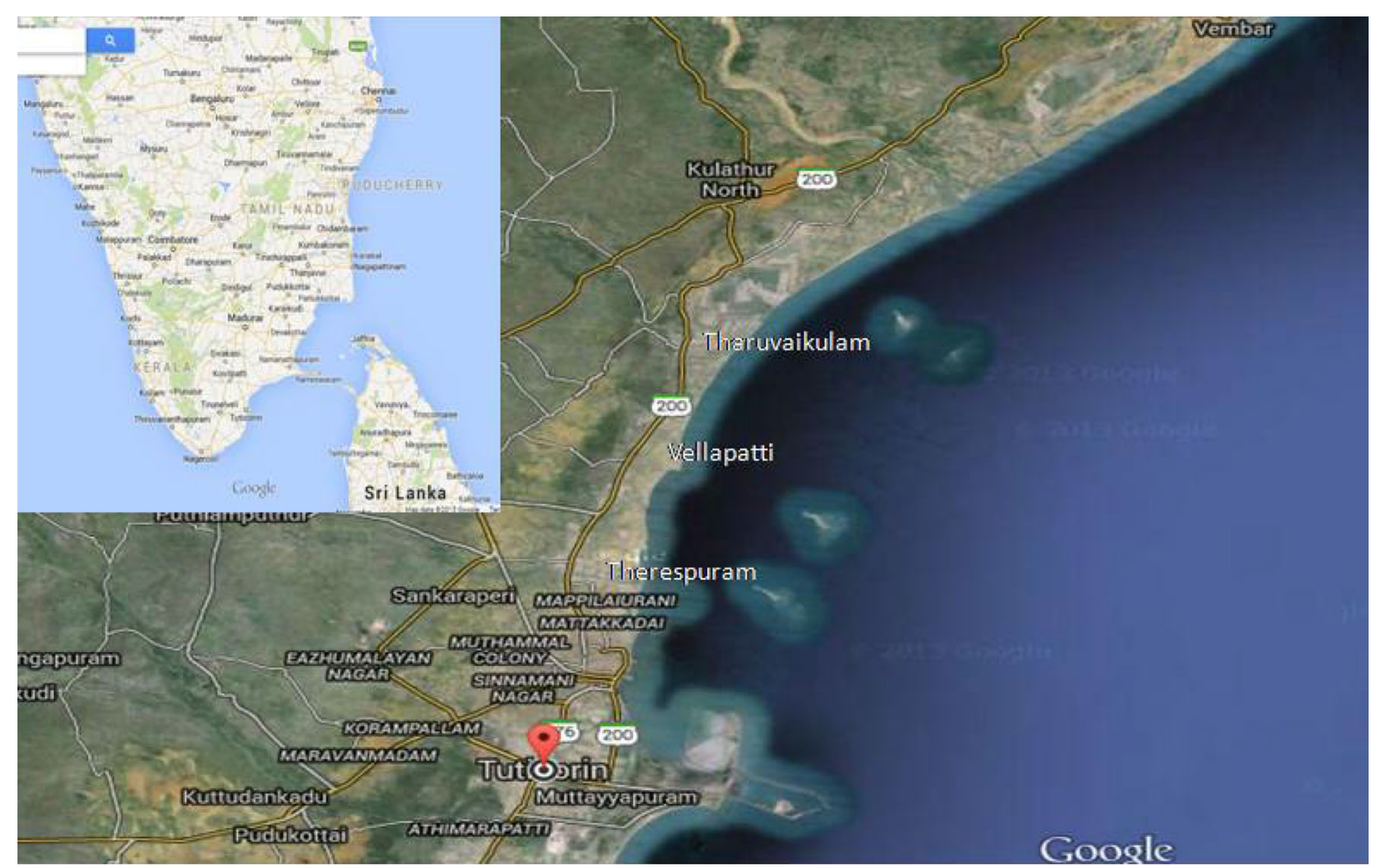

Fig. 1 Map showing the study area 
(station-I during June 2014) to 8.5 (station-III during May 2015)(Fig. 2c). The DO concentration varied between 4.125 and $4.963 \mathrm{mg} \mathrm{l}^{-1}$, registering maximum during December 2014 at station-I and minimum at station-II during August 2014 (Fig. 2d). Total alkalinity ranged from 64 to $99 \mathrm{mg} / \mathrm{l}$ with the maximum during April 2015 at station-II and minimum during June 2014 at station-I (Fig. 2e). Total suspended solids (TSS) ranged from 24 to $97 \mathrm{mg} / \mathrm{l}$ with the maximum during October 2014 at stationII and minimum during June 2014 at station-I (Fig. 2f). The nitrite concentration varied from 0.215 (February 2014 at station-III) to $0.840 \mu \mathrm{M} / 1$ (August 2014 at station-II) (Fig. 2g). The nitrate concentration ranged from 2.047 to $4.007 \mu \mathrm{M} / 1$. The minimum $\mathrm{NO}_{3}$ was observed during November 2014 and maximum was observed during May 2015 at station-III (Fig. 2h). The minimum inorganic phosphate concentration $(0.167 \mu \mathrm{M} / \mathrm{l})$ was recorded during September 2014 at station-III and the maximum concentration $(0.904 \mu \mathrm{M} / 1)$ was registered during December 2014 at station-II (Fig. 2i). The total phosphorus was maximum (1.039 $\mu \mathrm{M} / 1)$ during December 2014 and minimum concentration $3.479 \mu \mathrm{M} / \mathrm{l}$ was noticed at station-II during February 2015 (Fig. 2j). The reactive silicate concentration ranged from 3.737 to $8.876 \mu \mathrm{M} / 1$ with the higher value during November 2014 at station I and the lowest during June 2014 at station-II (Fig. 2k). The ammonia $\left(\mathrm{NH}_{4}\right)$ concentration ranged $0.078-0.526 \mu \mathrm{M} / 1$ with the maximum during October 2014 and minimum during July 2014 at station-II (Fig. 21).

\section{Discussion}

This short time series data may allow us to understand the effects of short time variations in the biological and physico-chemical conditions on the eutrophication in the coastal waters, southeast coast of India. Bay of Bengal is considered to be relatively less productive compared to its western counterpart Arabian Sea (Qasim 1977; Radhakrishna and Bhargava 1978; Prasanna Kumar et al. 2002); whereas, in monsoon seasons (southwest and northeast monsoon) the nutrient inputs from river runoff trigger primary production of the coastal waters of the Bay of Bengal (Gomes et al. 2000; Madhu et al. 2002; Madhupratap et al. 2003). Hence, the present study investigated the seasonal change in primary production in the southeast coast of India with respect to the prevailing hydrographical environment through planned systematic new data collections.

Generally, surface water temperature has been influenced by the intensity of solar radiation, evaporation, freshwater influx and cooling and mix-up with ebb and flow from adjoining neritic waters. Influence of temperature in phytoplankton community dynamics has been investigated for different species and certain phytoplankton species have been observed to have a unique temperature range for growth (Eppley 1972). Change in SST tend to alter biological, physical and chemical reactions within an organism, thus affecting community structure by selecting those best suited to survive (Dupuis and Hann 2009). The surface water temperature varied from 26.4 to $29.7{ }^{\circ} \mathrm{C}$ mainly with changes in monthly variations. Higher surface water temperature recorded during the May 2015 at station-III might be due to the increased solar radiation (Satpathy and Nair 1990; Richardson et al. 2000). Though the SST is capable of altering the reproduction, growth, metabolism, microbial processes and especially photosynthesis rates, the observed ranges are not alarming and are within the optimal range $\left(18.3-37.8^{\circ} \mathrm{C}\right)$ for production of plankton in tropical waters (Hossain et al. 2007; Shah et al. 2008).

Salinity did not fluctuate much between the seasons registering the maximum (36.2\%o) during May 2015 at station III, coinciding with the low amount of rainfall and higher rate of evaporation (Govindasamy et al. 2000) prevailing in the region during this season. The salinity is the main physical parameter that can be attributed to the plankton diversity which acts as a limiting factor and influences the distribution of planktonic community (Kouwenberg 1994; Neelam and Nair 1997; Chandramohan and Sreenivas 1998; Balasubramanian and Kannan 2005; Sridhar et al. 2006). pH was maximum in March 2011 at station I due to the influence of daily photosynthetic activity by phytoplanktons (Das et al. 1997) which removes dissolved carbon dioxide in the water column thereby increasing the $\mathrm{pH}$ level. Generally, fluctuations in $\mathrm{pH}$ values during different seasons of the year can be attributed to factors like removal of $\mathrm{CO}_{2}$ by photosynthesis through bicarbonate degradation, dilution of seawater by freshwater influx, reduction of salinity and temperature and decomposition of organic matter as stated by Upadhyay (1998), Rajasegar (2003), and Paramasivam and Kannan (2005). The observed high $\mathrm{pH}$ values might be due to the influence of seawater inundation and the high density of phytoplankton (Das et al. 1997; Subramanian and Mahadevan 1999).

The DO level varied between $4.125 \mathrm{mg} \mathrm{l}^{-1}$ (August 2014) and $4.963 \mathrm{mg} \mathrm{l}^{-1}$ (December 2014). Salinity and SST show negative relationship with phytoplankton biomass, whereas DO represent the balance between photosynthesis and respiration and showed a positive relationship. The increased DO (4.963 $\left.\mathrm{mg} \mathrm{l}^{-1}\right)$ level during December 2014 can be attributed to comparatively less SST and salinity recorded during this season and above all the turbulent nature of the sea during this season triggers vertical mixing of water column. Present findings are contradictory to the earlier reports (Satpathy et al. 2009) 
that recorded increased DO level from August 2014 to December 2014 in this part of Bay of Bengal.

The silicate content was higher than that of all other nutrients except the total nitrogen registering maximum during November $2014(8.876 \mu \mathrm{M} / \mathrm{l})$. This could be largely

a

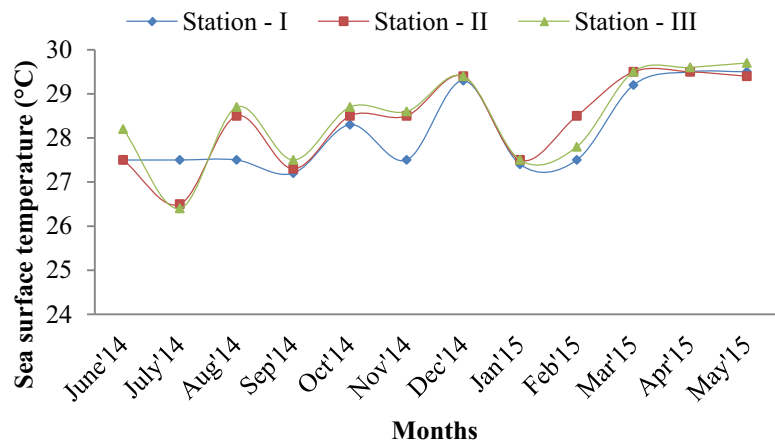

c

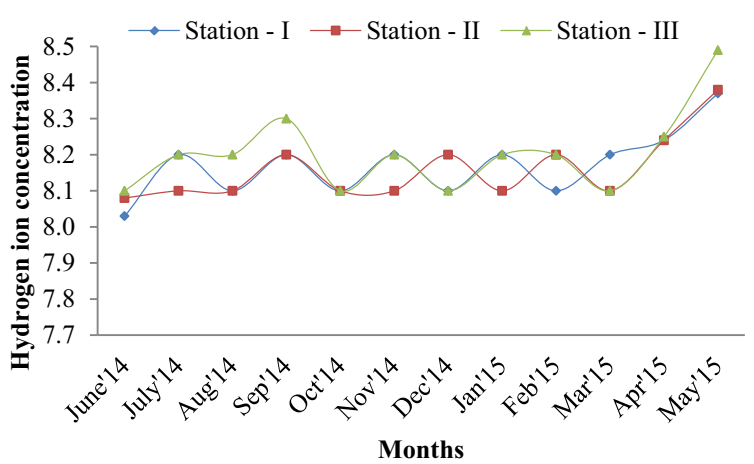

e
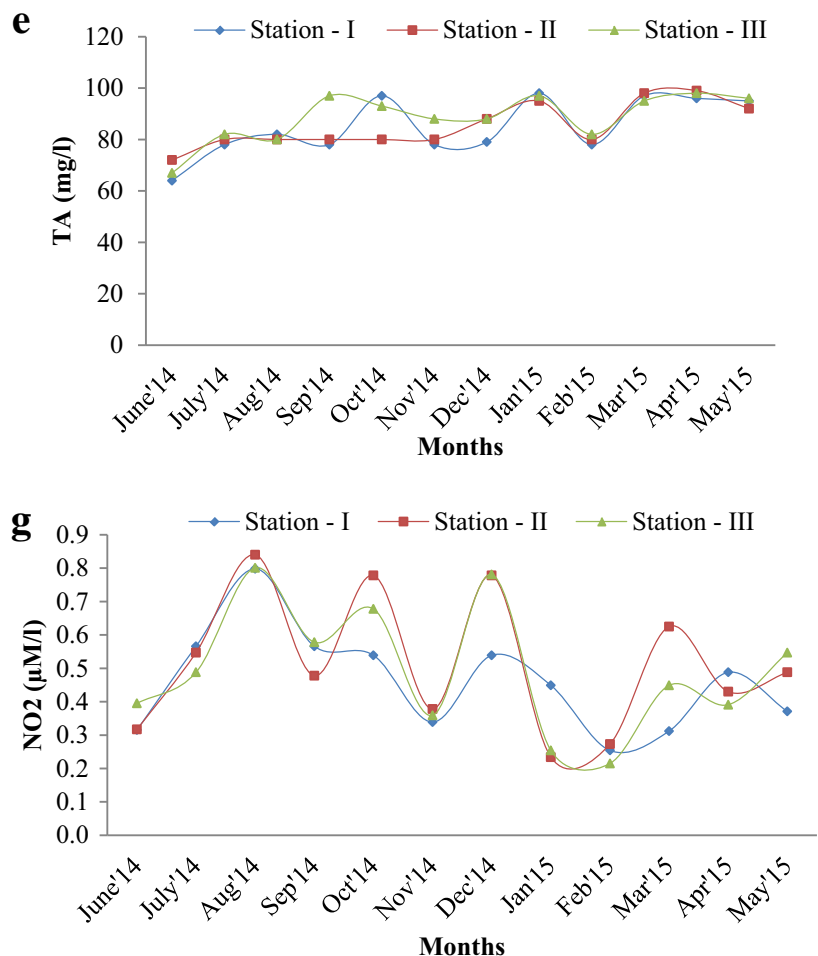

due to the heavy inflow of monsoon inputs. In coastal waters, apart from the physical mixing of seawater with freshwater, factors like adsorption of reactive silicate from suspended sedimentary particles, chemical interaction with clay minerals, co-precipitation with humid substances and
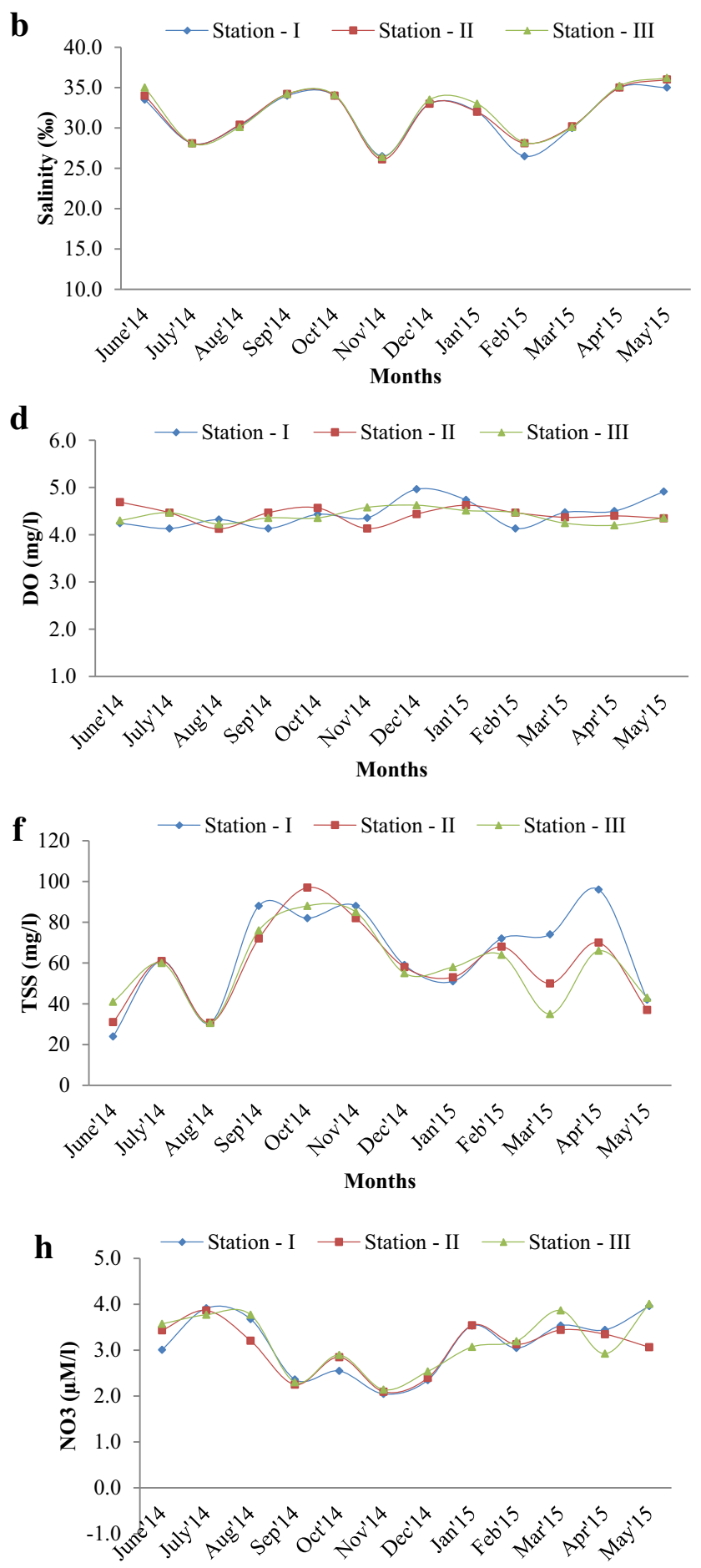

Months

Fig. 2 Physico-Chemical characteristics of Tuticorin coastal waters during June 2014 to May 2015 

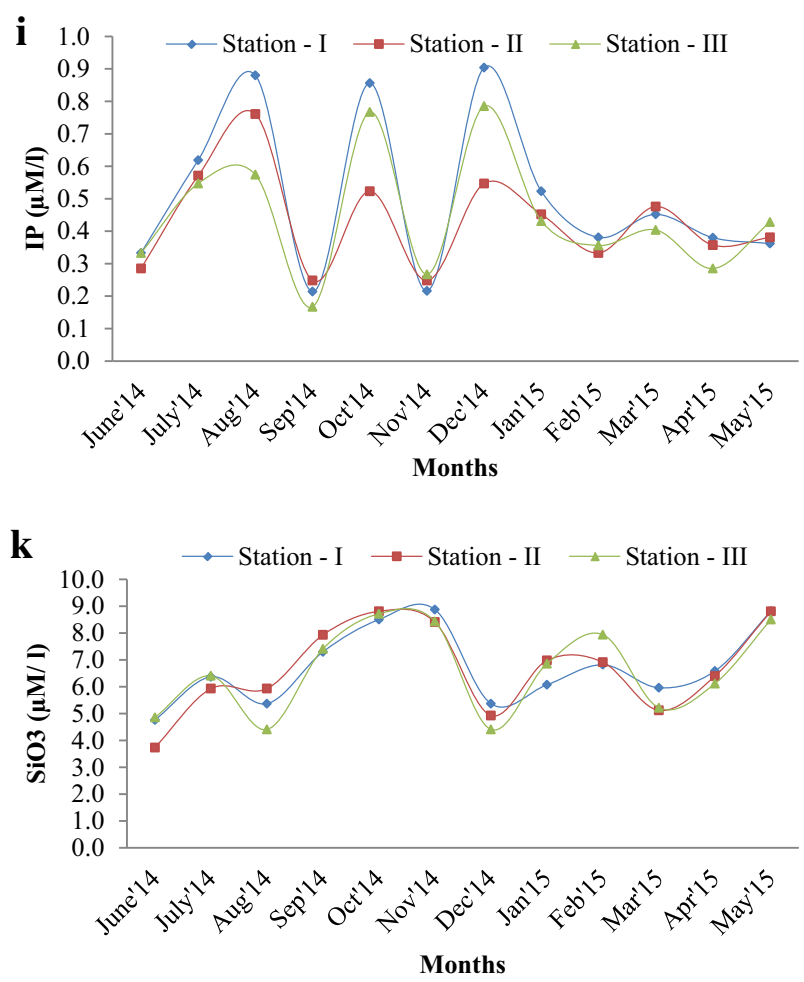

Fig. 2 continued

biological removal by phytoplankton (diatoms and silicoflagellates) can significantly influence the spatio-temporal variation of silicate (Satpathy et al. 2010). Phosphate concentration in coastal waters was influenced by the mixing of the freshwater with the seawater in the land-sea interaction zone, addition through localized upwelling and uptake of phytoplankton (Satpathy et al. 2010). Maximum inorganic phosphate $(0.904 \mu \mathrm{M} / \mathrm{l})$ concentration was recorded during December 2014 while low concentration $(0.167 \mu \mathrm{M} / \mathrm{l})$ was observed during September 2014. This might be possibly due to the utilization of phosphate by the increased phytoplankton population during the season. The maximum level $(3.479 \mu \mathrm{M} / 1)$ of total phosphorous (TP) was recorded during December 2014 and the minimum $(1.039 \mu \mathrm{M} / \mathrm{l})$ was recorded during February 2015 which also support the above fact. The limiting nutrient concentrations vary with season, location and phytoplankton community structure (Fisher et al. 1992), and phosphate is one of the important organic nutrients that can limit the phytoplankton population in tropical waters.

The present study showed the abundance of nutrients at the southern Bay that might have resulted due to the discharge of nutrient-rich water from the rivers at the southeast coast of India to the Bay of Bengal during southwest monsoon season.

Salinity and nitrate concentration was low and reactive silicate, and inorganic phosphates are moderate. Silicate,
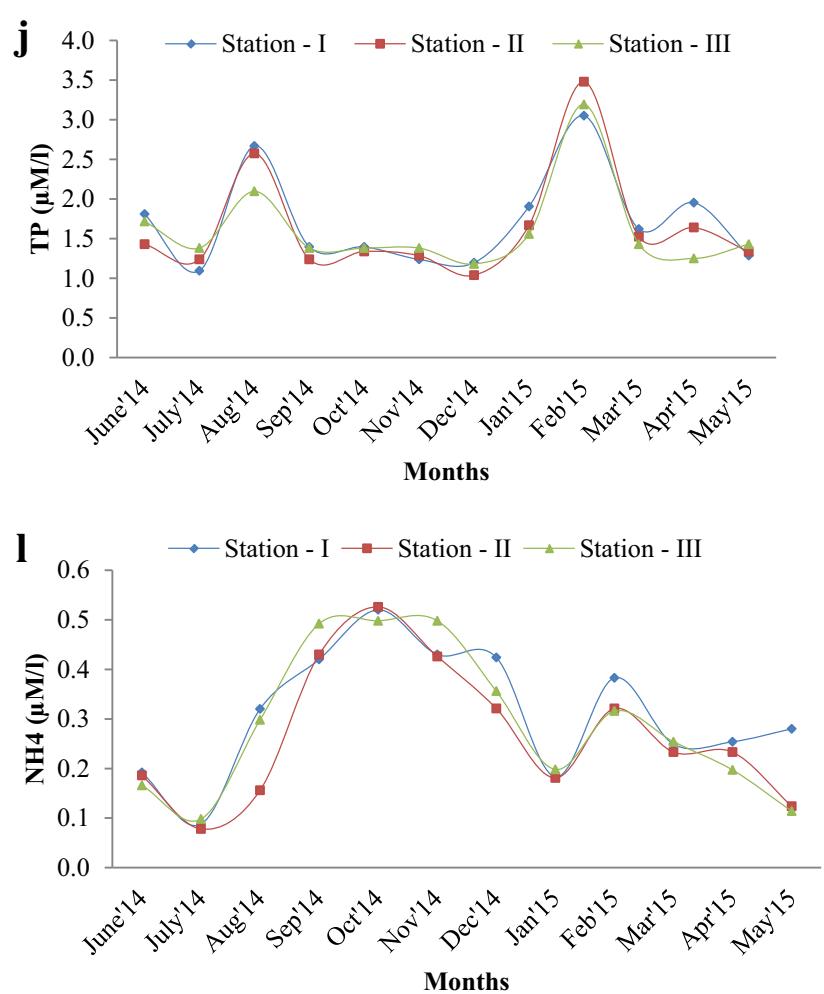

nitrate and phosphate ratios are therefore useful for predicting the phytoplankton abundance and assemblages in the tropical coastal waters. The ability to identify limiting nutrients has thus becomes of considerable importance for our understanding of the plankton ecology (Havens 2000). However, such limiting nutrient factors vary for closed water bodies and water bodies influenced by the external discharges.

\section{Conclusion}

The present study attempted to record the seasonal variations of hydrographical parameters along the southeast coast of India. Analyses of our data sets revealed that the southwest of Bay of Bengal does not exhibit a large-scale spatial variability. All the hydrographical parameters showed clear seasonal patterns, and are typical to the tropical marine environment without any marked variation between the stations. Increased thermal stratification especially on surface waters and utilization of essential nutrients by phytoplankton makes the Bay of Bengal oligotrophic during summer when there is no external input. Tuticorin coastal water is subjected to seasonal fluctuations in physico-chemical parameters depending upon the seasonal tidal amplitude and freshwater influx resulting in a continuous exchange of organic, inorganic, plant and animal matters. 
Acknowledgments The authors wish to thank the authorities of Kamaraj College, Manonmaniam Sundaranar University, for providing the necessary facilities, and the authors thank the INCOIS -OSF Project (Grant No: F\&A:OSF/A2:XII:014.Dt06/06/2014), Ministry of Earth Sciences (MoES) (Government of India) for their financial support.

Open Access This article is distributed under the terms of the Creative Commons Attribution 4.0 International License (http:// creativecommons.org/licenses/by/4.0/), which permits unrestricted use, distribution, and reproduction in any medium, provided you give appropriate credit to the original author(s) and the source, provide a link to the Creative Commons license, and indicate if changes were made.

\section{References}

Anilkumar N, Dineshkumar PK (2002) A study on the seasonal dynamics of Beypore estuary, Kerala coast. Indian J Mar Sci 31:52-58

Balasubramanian R, Kannan L (2005) Physico-chemical characteristics of the coral reef environs of the Gulf of Mannar biosphere reserve, India. Int J Ecol Environ Sci 31:265-271

Chandramohan P, Sreenivas N (1998) Diel variations in zooplankton population in mangrove ecosystem at Gaderu canal, South-east coast of India. Indian J Mar Sci 27:486-488

Das J, Das SN, Sahoo RK (1997) Semidiurnal variation of some physicochemical parameters in the Mahanadi estuary, east coast of India. Indian J Mar Sci 26:323-326

Dupuis A, Hann BJ (2009) Warm spring and summer water temperatures in small eutrophic lakes of the Canadian prairies: potential implications for phytoplankton and zooplankton. J Plankton Res 31:489-502

Eppley RW (1972) Temperature and phytoplankton growth in the sea. Fish Bull 70:1063-1085

Fisher TR, Peele ER, Ammerman JW (1992) Nutrient limitation of phytoplankton in Chesapeake Bay. Mar Ecol Prog Ser 82:51-63

Gomes HR, Goes JI, Saino T (2000) Influence of physical processes and freshwater discharge on the seasonality of phytoplankton regime in the Bay of Bengal. Cont Shelf Res 2:313-330

Govindasamy C, Kannan L, Jayapaul A (2000) Seasonal variation in physico-chemical properties and primary production in the coastal water biotopes of Coromandel coast, India. J Environ Biol 21:1-7

Havens KE (2000) Using trophic state index values to draw inferences regarding phytoplankton limiting factors and seston composition from routine water quality monitoring data. Korean J Limnol 33:187-196

Hossain MY, Jasmine S, Ibrahim AHM (2007) A preliminary observation on water quality and plankton of an earthen Fish Pond in Bangladesh: recommendations for future studies. Pak J Biol Sci 10:868-873

Karr JR, Allen JD, Benke AC (2000) River conservation in the United States and Canada. In: Boon PJ, Davies BR, Petts GE (eds) Global perspectives on river conservation. Science, policy, and practice. Wiley, New York pp 3-39

Kouwenberg JHM (1994) Copepod distribution in relation to seasonal hydrographic and spatial structure in the north-western Mediterranean (Gulf du Lion). Estuar Coast Shelf Sci 38:69-90

Madhu NV, Maheswaran PA, Jyothibabu R (2002) Enhanced biological production off Chennai triggered by October 1999 super cyclone (Orissa). Curr Sci 82(12):1472-1479
Madhupratap M, Gauns M, Ramaiah N (2003) Biogeochemistry of the Bay of Bengal: physical, chemical and primary productivity during summer monsoon. Deep Sea Res 50:881-896

Mishra A (2010) Assessment of water quality using principal component analysis: a case study of the river Ganges. J Water Chem Technol 32(4):227-234

Neelam Ramaiah, Nair Vijayalakshmi (1997) Distribution and abundance of copepods in the pollution gradient zones of Bombay harbour- Thanecreek- Basin creek, West coast of India. Indian J Mar Sci 26:20-25

Paramasivam S, Kannan L (2005) Physico-chemical characteristics of Muthupettai mangrove environment, southeast coast of India. Int J Ecol Environ Sci 31:273-278

Perumal P, Sampathkumar P, Karuppasamy PK (1999) Studies on the bloom forming species of phytoplankton in the Vellar estuary, southeast coast of India. Indian J Mar Sci 28:400-403

Prasanna Kumar S, Muraleedharan PM, Prasad TG (2002) Why is the Bay of Bengal less productive during SM as compared to the Arabian Sea? Geophys Res Lett 29(24):2238-2435

Qasim SZ (1977) Biological productivity of the Indian Ocean. Indian J Mar Sci 6:122-137

Radhakrishna K, Devassy VP, Bhargava RMS (1978) Primary production in the Northern Arabian Sea, Indian J Mar Sci 7:271-275

Rajasegar M (2003) Physico-chemical characteristics of the Vellar estuary in relation to shrimp farming. J Environ Biol 24:95-101

Richardson TL, Gibson CE, Heaney SI (2000) Temperature, growth and seasonal succession of Phytoplankton in Lake Baikal, Siberi. Freshw Biol 44:431-440

Sala OE, Chapin FS, Armesto JJ, Berlow E, Bloomfield J, Dirzo R, Huber-Sanwald E, Huenneke LF, Jackson RB, Kinzig A, Leemans R, Lodge DM, Mooney HA, Oesterheld M, Poff NL, Sykes MT, Walker BH, Walker M, Wall DH (2000) Global biodiversity scenarios for the year 2100. Science 287:1770-1774

Satpathy KK, Nair KVK (1990) Impact of power plant discharge on the physico-chemical characteristics of Kalpakkam coastal waters. Mahasagar 23:117-125

Satpathy KK, Sahu G, Mohanty AK et al (2009) Phytoplankton community structure and its variability during southwest to northeast monsoon transition in the coastal waters of Kalpakkam, east coast of India. Int J Ocean Oceanogr 3(1):43-74

Satpathy KK, Mohanty AK, Natesan U (2010) Seasonal variation in physicochemical properties of coastal waters of Kalpakkam, east coast of India with special emphasis on nutrients. Environ Monit Assess 164:153-171

Shah MMR, Hossain MY, Begum M (2008) Seasonal variations of phytoplanktonic community structure and production in relation to environmental factors of the Southwest Coastal waters of Bangladesh. J Fish Aquat Sci 3:102-113

Sridhar R, Thangaradjou T, Senthil Kumar S (2006) Water quality and phytoplankton characteristics in the Palk Bay, southeast coast of India. J Environ Biol 27:561-566

Strickland JDH, Parsons TR (1972) A practical handbook of seawater analysis. Bull Fish Res Bd Canada 167:311-312

Subramanian B, Mahadevan A (1999) Seasonal and diurnal variations of hydro biological characters of coastal waters of Chennai (Madras) Bay of Bengal. Indian J Mar Sci 28:429-433

Thillai Rajasekar K, Perumal P, Santhanam P (2005) Phytoplankton diversity in the Coleroon estuary, southeast coast of India. J Mar Biol Ass India 47:127-132

Upadhyay S (1998) Physico-chemical characteristics of the Mahanadhi estuarine ecosystem, east coast of India. Indian J Mar Sci 17:19-23 